\title{
DESAIN BAHAN AJAR MATA KULIAH ALJABAR LINEAR UNTUK MENGEMBANGKAN KEMAMPUAN BERPIKIR KREATIF MATEMATIS
}

\author{
Mahyudi $^{1}$, Nyayu M. Ariani $^{2}$, Winda Ramadianti ${ }^{3}$ \\ Universitas Muhammadiyah Bengkulu \\ 1didimahyudi21@gmail.com \\ ${ }^{2}$ nyayu.masyita@ymail.com \\ ${ }^{3}$ winda.ramadianti@gmail.com
}

\begin{abstract}
ABSTRAK
Salah satu pendukung dalam keberhasilan kegiatan pembelajaran adalah adanya bahan belajar yang baik terutama sebagai penunjang aktivitas belajar mahasiswa. Referensi yang sering digunakan dalam perkuliahan adalah buku teks dari penerbit. Akan tetapi, pemanfaatan buku tersebut kurang dapat membuat mahasiswa belajar secara lebih aktif. Berdasarkan pengalaman mengajar didapatkan kebanyakan mahasiswa sangat tergantung dengan penjelasan dosen padahal alokasi waktu yang tersedia tidak memungkinkan dapat menjelaskan materi secara menyeluruh. Penggunaan sumber seperti buku teks terkadang hanya digunakan setelah perkuliahan bukan sebelum perkuliahan. Selain itu referensi yang tersedia lebih banyak menekankan pada penyampaian informasi saja dan penyajiannya kurang dapat mengkonstruksi pengetahuan mahasiswa itu sendiri. Hal ini menjadikan paradigma belajar student centre yang diharapkan, tidak berjalan sebagimana mestinya. Peneliti bersama-sama merancang bahan ajar berdasarkan kemampuan, potensi, dan situasi yang ada. Tahap perancangan akan menghasilkan draf bahan ajar yang dievaluasi berdasarkan evaluasi materi yang meliputi antara lain, kelayakan isi, kebahasaan, sajian dan kegrafikan serta evaluasi dari segi konstruk antara lain memperhatikan ketepatan dalam susunan, tidak menimbulkan penafsiran ganda dan benar-benar mengukur kemampuan berfikir kreatif. Selanjutnya draf diujicobakan dalam skala kecil dengan 10 orang responden yang sudah pernah mendapat kuliah Aljabar Linear dan uji coba lapangan pada kegiatan pembelajaran mata kuliah Aljabar Linear. Modul dan Lembar Kegiatan Mahasiswa (LKM) yang dikembangkan sudah valid dan layak diujicobakan pada proses pembelajaran untuk dapat memfasilitasi kemampuan berfikir kreatif matematis. Bahan ajar tersebut menarik dan dapat menimbulkan motivasi belajar di tengah keterbatasan bahan ajar dan mengurangi rasa malas belajar di rumah.
\end{abstract}

Kata Kunci : Modul, LKM, Kemampuan Berfikir Kreatif Matematis.

\section{PENDAHULUAN}

Salah satu tujuan pendidikan adalah mengembangkan kemampuan berpikir, khususnya pendidikan matematika yang berperan aktif dalam pada berbagai disiplin ilmu dan memajukan daya pikir manusia. Matematika menjadi sarana untuk menumbuhkembangan kemampuan berpikir logis, cermat dan kreatif. Oleh karena itu, kurikulum di pendidikan tinggi pun harus menjadikan pengembangan kemampuan ini 
menjadi bagian di dalamnya dan terintegrasi dalam setiap mata kuliah terutama pada jurusan matematika.

Perkuliahan Aljabar Linear meruapakan bagian penting pada pembelajaran matematika di perguruan tinggi, perlu dikuasai oleh mahasiswa dengan baik karena cukup banyak dipakai pada materi lain seperti program linear dan kalkulus lanjut. Aljabar Linear memberi pengetahuan tentang sistem persamaan linear dan matriks. Mahasiswa perlu mempelajari mata kuliah ini karena tidak hanya sebagai materi prasyarat, tetapi sudah cukup banyak aplikasi aljabar linear terutama matriks pada ilmu-ilmu lain seperti pengelolaaan hutan, rekonstruksi aljabar dan pembuatan kode.

Pemanfaatan materi ini dalam aplikasinya pada ilmu-ilmu lain menuntut pemahaman mahasiswa secara mendalam terutama pada pemahaman konsep itu sendiri dan pengembangan kemampuan berpikir secara kreatif. Akan tetapi, pada kenyataannya masih banyak mahasiswa yang belum memiliki pengetahuan yang mendalam tentang konsep materi tersebut. Hal ini tidak hanya berimbas pada kurangnya kreativitas dalam menyelesaikan permasalahan pada materi ini, tetapi lebih jauh mengakibatkan hasil belajar yang rendah pada mata kuliah tersebut.

Pemahaman mahasiswa terhadap materi ini perlu diperbaiki dengan tindakan yang tepat agar dapat memudahkan dalam memahami konsep serta dapat merangsang kemampuan berpikir dalam menggali dan memaksimalkan kompetensi yang dimilki mahasiswa, sehingga dapat meningkatkan prestasi belajar mahasiswa dan tujuan dari proses pembelajaran dapat dicapai dengan baik.

Pemilihan dan penggunaan sumber belajar yang tepat dalam suatu aktivitas dan proses pembelajaran berperan penting dalam mengarahkan pengalaman belajar mahasiswa. Menurut Rudi (2010:5) sumber belajar seperti modul akan membuat proses belajar mengajar lebih efektif, efisien dan relevan. Dalam hal ini, pengembangan bahan ajar diharapkan akan dapat membuat kemampuan berpikir kreatif matematis menjadi lebih baik.

Saat ini, materi pembelajaran mata kuliah Aljabar Linear tidak hanya dari buku ajar/buku teks, tetapi tersebar pada berbagai sumber seperti e-jurnal, e-book, jurnal ilmiah dan hasil-hasil publikasi dalm bentuk buletin. Sumber-sumber tersebut saling melengkapi sehingga perlu untuk mendapatkan seluruh materi tersebut. Tetapi ketersediaan sumbersumber tersebut tidak menjadikan mahasiswa untuk berusaha mengumpulkannya. Mahasiswa lebih banyak bergantung pada dosen sehingga proses pembelajaran menjadi 
pasif. Dosen menjadi satu-satunya sumber belajar di kelas seperti yang diungkapkan Trisnaningsih (2007) bahwa mahasiswa cenderung hanya mendengarkan, akibatnya banyak waktu tersita untuk menjelaskan materi. Selain itu, bahan referensi belajar yang ada tersebut belum menuntut mahasiswa dalam mengembangkan pengetahuan terutama dalam kemampuan berpikir kreatif matematis.

Pengembangan bahan ajar adalah sebagai bentuk aktivitas dan proses belajar mengajar dapat membuat kualitas pembelajaran yang ada menjadi lebih baik. Bahan ajar tersebut dapat menghimpun materi-materi dari berbagai sumber sehingga lebih bervariasi dan dapat memberikan pengalaman belajar yang lebih kepada mahasiswa terutama dalam pengembangan kemampuan berpikir kreatif.

Berdasarkan uraian yang telah dikemukakan dapat diidentifikasi permasalahan sebagai berikut:

1. Rendahnya kebrhasilan belajar mahasiswa pada materi Aljabar Linear.

2. Bahan ajar yang ada kurang menuntut mahasiswa dalam mengkonstruksi pengetahuannya sendiri terutama dalam pengembangan kemampuan berpikir kreatif matematis.

Masalah utama pada kajian ini adalah apakah dengan pengembangan bahan ajar Aljabar Linear serta proses pembelajarannya yang secara optimal dapat mengembangkan kemampuan berpikir kreatif matematis mahasiswa Program Studi Pendidikan matematika FKIP Universitas Muhammadiyah Bengkulu.

Asumsi yang dijadikan landasan dalam penelitianan ini adalah bahwa bahan ajar yang dikembangkan disusun berdasarkan alur penelitian pengembangan dan dosen memiliki pengetahuan tentang materi yang dikembangkan serta ahli/validator mempunyai pemahaman yang sama tentang kualitas bahan ajar yang baik.

Luaran berupa bahan ajar yang dihasilkan memiliki keterbatasan antara lain materi yang digunakan hanya terbatas pada Himpunan Penyelesaian Sistem Persamaan Linear dengan Matriks dan Determianan Matriks, kualitas atau mutu bahan ajar yang dikembangkan ditinjau dari dua sampai tiga orang ahli/validator serta bahan ajar hasil pengembangan hanya diujicobakan pada mahasiswa Program Studi Pendidikan Matematika FKIP Universitas Muhammadiyah Bengkulu. 


\section{Pengembangan Bahan Ajar di Perguruan Tinggi}

Pengembangan bahan ajar merupakan salah satu bentuk dari kegiatan proses pembelajaran untuk memperbaiki atau meningkatkan kualitas pembelajaran yang berlangsung. Menurut Ahmad (2009), dalam dharma pengajaran, setiap dosen dituntut untuk mempersiapkan diri dalam pembelajaran di kelas dengan menyusun GBPP, bahan ajar dan satuan acara perkuliahan. Mengembangkan bahan ajar sudah selayaknya merupakan kemampuan yang harus terus menerus ditingkatkan oleh setiap dosen. Situasi pembelajaran jadi monoton dan cenderung membosankan bagi mahasiswa, apabila seorang dosen tidak mempunyai kemampuan dalam membuat bahan ajar yang bervariasi

Bahan ajar dibuat untuk membantu para mahasiswa dapat dengan cepat memahami pengetahuan dan keterampilan yang dipelajari. Penyediaan bahan ajar yang lengkap dan mudah diperoleh serta dapat dilakukan berulang-ulang akan membuat mahasiswa betah dan menerima pengetahuan dengan baik dalam mencapai kompetensi yang telah ditetapkan.

Bahan ajar merupakan bagian yang penting dalam pembelajaran karena dapat digunakan sebagai sumber belajar baik bagi dosen maupun mahasiswa. Menurut Suprawoto (2009: 1), ada beberapa pengertian bahan ajar: 1) Bahan ajar adalah segala bentuk bahan yang digunakan oleh pengajar dalam melaksanakan kegiatan belajar mengajar di kelas. Bahan yang dimaksud berupa bahan bahan tertulis atau bahan tidak tertulis. 2) sebagai sumber data/keterangan, alat dan/atau teks yang dibutuhkan oleh dosen dalam membuat rencana dan penelaahan aplikasi pembelajaran. 3) Bahan ajar adalah seperangkat materi yang disusun secara sistematis baik tertulis maupun tidak sehingga tercipta lingkungan/suasana yang memungkinkan siswa untuk belajar.

Penggunaan bahan ajar dalam proses perkuliahan merupakan salah satu cara untuk mengatasi situasi pembelajaran yang monoton dan cenderung pasif. Dosen akan terbantu untuk mengurangi waktu dalam menjelaskan materi ajar. Mahasiswa akan lebih dapat mengembangkan kemampuannya dan terbantu dalam proses belajarnya. Hal ini meunjukkan bahwa pembelajaran dengan mengunakan bahan ajar seperti modul dan lembar kerja mahasiswa dapat memberikan manfaat dalam proses pembelajaran yang tidak hanya dirasakan oleh mahasiswa, akan tetapi juga dosen yang bersangkutan dan perguruan tinggi pada umumnya dalam menyelesikan kurikulum. 


\section{Kemampuan Berpikir Kreatif Matematis}

Berpikir kreatif merupakan suatu prosedur yang dipakai pada saat munculnya suatu gagasan baru. Ide-ide akan dapat dihasilkan ketika seseorang mengaplikasikan berpikir kreatif pada suatu proses problem solving, da n pemikiran divergen (Pehkonen, dalam Siswono, 2009). Hal ini akan berguna dalam menemukan penyelesaiannya.

Pengembangan kemampuan berpikir kreatif merupakan salah satu fokus pembelajaran matematika. Demikian halnya juga dengan pembelajaran mata kuliah- mata kuliah di perguruan tinggi, khususnya pada program studi Matematika. Apa sebenarnya kemampuan berpikir kreatif itu? Telah begitu banyak ahli yang membahas tentang berpikir kreatif baik kreatif secara umum maupun berpikir kreatif matematis.

Menurut Isaksen et al (Grieshober, 2004), berpikir kreatif sebagai proses konstruksi ide yang menekankan pada aspek kelancaran, keluwesan, kebaruan, dan keterincian. Menurut McGregor (2007), berpikir kreatif adalah ketika munculnya wawasan baru, pendekatan baru, perspektif baru, atau cara baru dalam memahami sesuatu sebagai akibat dari proses berpikir. Sementara menurut Martin (2009), kemampuan berpikir kreatif adalah kemampuan untuk menghasilkan gagasan atau metode baru dalam menghasilkan suatu produk.

Bagaimana dengan kreativitas dalam matematika? Menurut Pehnoken dalam Mahmudi, 2010) kreativitas tidak hanya terjadi pada bidang-bidang tertentu, seperti seni, sastra, atau sains, melainkan juga ditemukan dalam berbagai bidang kehidupan, termasuk matematika. Kreatif dalam matematika lebih ditekankan pada proses berpikir itu sendiri. Karenanya, kreativitas dalam matematika lebih tepat diistilahkan sebagai berpikir kreatif matematis. Walaupun begitu, istilah kreativitas dalam matematika atau berpikir kreatif matematis dianggap mempunyai makna yang sama, sehingga dapat digunakan secara bergantian.

Krutetski (Park, 2004) mendefinisikan bahwa apabila ditemukannya solusi matematika secara lebih mudah dan fleksibel maka dianggap sebagai kemampuan berpikir kreatif matematis. Holland (Mann, 2005) mengidentifikasi aspek-aspek kemampuan berpikir kreatif matematis, yaitu kelancaran, keluwesan, keaslian, elaborasi, dan sensitivitas. Menurut Livne (2008), berpikir kreatif matematis merujuk pada kemampuan untuk menghasilkan solusi bervariasi yang bersifat baru terhadap masalah matematika yang bersifat terbuka. 
Untuk dapat mengukur kemampuan berpikir kreatif matematis perlu dikembangkan instrumen yang baik dan ditunjang dengan bahan ajar yang dapat melatih kemampuan tersebut. Menurut Worthington (2006), mengukur kemampuan berpikir kreatif siswa dapat dilakukan dengan cara mengeksplorasi hasil kerja siswa yang merepresentasikan proses berpikir kreatifnya. Sementara menurut McGregor (2007), mengukur kemampuan berpikir kreatif siswa dapat pula dilakukan dengan mendasarkan pada apa yang dikomunikasikan siswa, secara verbal maupun tertulis.

Dalam penelitian ini, seperti dikutip dari Mahmudi (2010), aspek-aspek kemampuan berpikir kreatif matematis adalah kelancaran, keluwesan, kebaruan, dan keterincian. Aspek kelancaran meliputi kemampuan menyelesaikan masalah dan memberikan banyak jawaban terhadap masalah tersebut, atau memberikan banyak contoh atau pernyataan terkait konsep atau situasi matematis tertentu. Aspek keluwesan meliputi kemampuan menggunakan beragam strategi penyelesaian masalah, memberikan beragam contoh atau pernyataan terkait konsep atau situasi matematis tertentu. Aspek kebaruan meliputi kemampuan menggunakan strategi yang bersifat baru, unik, atau tidak biasa untuk menyelesaikan masalah, atau memberikan contoh atau pernyataan yang bersifat baru, unik, atau tidak biasa. Aspek keterincian meliputi kemampuan menjelaskan secara terperinci, runtut, dan koheren terhadap prosedur matematis, jawaban, atau situasi matematis tertentu. Penjelasan ini menggunakan konsep, representasi, istilah, atau notasi matematis yang sesuai.

\section{METODE PENELITIAN}

Studi ini merupakan kegiatan pengembangan yang dilakukan secara kolaborasi antara dosen dan mahasiswa. Dosen merupakan tim peneliti yang akan duduk bersama untuk merancang bahan ajar berdasarkan pengalaman, potensi, dan kondisi yang ada. Dari kegiatan perancangan akan menghasilkan draf bahan ajar. Draf ini dievaluasi berdasarkan evaluasi materi yang meliputi antara lain, kelayakan isi, kebahasaan, ssajian dan kegrafikan serta evaluasi dari segi konstruk antara lain meninjau tentang ketepatan dalam susunan, tidak menimbulkan penafsiran ganda dan benar-benar mengukur kemampuan berfikir kreatif. Selanjutnya draf ini diujicobakan dalam skala kecil sebanyak 10 orang responden yang telah memperoleh materi Aljabar Linear dan uji coba lapangan pada kegiatan pembelajaran mata kuliah Aljabar Linear. Kegiatan uji coba ini akan selalu dibarengi proses evaluasi dan refleksi dalam upaya penyempurnaan bahan ajar. 
Prosedur penelitian pengembangan yang digunakan menurut Borg dan Gall sebagaimana yang dikutip oleh Soenarto (2005:8) yaitu menggunakan lima langkah utama, yaitu:

1. Melakukan analisis produk yang akan dikembangkan:

a. Identifikasi kebutuhan pengajaran \& menentukan tujuan umum pembelajaran

b. Analisis karakteristik mahasiswa dan konteks

c. Memilih dan mengembangkan materi pembelajaran

d. Merumuskan aktivitas-aktivitas yang sesuai

2. Mengembangkan produk awal:

a. Pengorganisasian materi yang telah ditentukan

b. Perumusan rancangan modul dan lembar kegiatan mahasiswa

3. Validasi ahli dan revisi:

Pada tahap ini dilakukan validasi isi dan konstruk oleh teman sejawat terutama dari segi materi mata kuliah, segi multi media untuk melihat layout dan dari segi instruksional untuk melihat segi konstruk, kemudian dilakukan analisis konseptual dan Revisi I.

4. Uji coba lapangan skala kecil dan revisi produk:

Uji Coba Kelompok Kecil, dilakukan uji terbatas terhadap kelompok kecil sebanyak 10 mahasiswa sebagai pengguna produk, kemudian dilakukan Revisi II.

5. Uji coba lapangan skala besar dan produk akhir:

Pada tahap ini dilakukan uji coba terhadap kelompok pengguna yang sebenarnya yaitu mahasiswa Program Studi Pendidikan Matematika FKIP Universitas Muhammadiyah Bengkulu.

\section{HASIL DAN PEMBAHASAN}

Pada penelitian ini ada dua bahan ajar yang dikembangkan yaitu modul dan lembar kegiatan mahasiswa. Model pengembangan tersebut melalui lima langkah sesuai dengan tahapan penelitian. Tahap awal ini dimulai dengan mengidentifikasi seluruh isi materi mata kuliah Aljabar Linear sesuai silabus yang berlaku di Program Studi Pendidikan Matematika FKIP Universitas Muhammadiyah Bengkulu. Analisis terhadap materi pada kurikulum mata kuliah Aljabar Linear diperoleh bahwa sebagian besar masih menekankan pada penanaman pemahaman konsep. Meskipun demikian pada instrumen yang ada pada kurikulum tersebut, sudah menekankan juga kemampuan berfikir kreatif terutama agar mahasiswa dapat melakukan proses pemahaman dengan mencoba alternatif jawaban 
sendiri. Selain analisis materi, juga dilakukan analisis mahasiswa sebagai peserta didik.

Analisis terhadap karakteristik mahasiswa digunakan sebagai gambaran untuk merancang dan mengembangkan bahan ajar Aljabar Linear. Materi-materi pada mata kuliah ini merupakan lanjutan materi yang telah mereka peroleh pada mata kuliah Aljabar Matriks. Selain itu, pada waktu SMA juga sudah dikenalkan tentang konsep-konsep dasar matriks. Analisis terhadap mahasiswa Prodi Pendidikan Matematika FKIP Universitas Muhammadiyah Bengkulu juga diperoleh bahwa sebagian besar berasal dari sekolahsekolah di luar Kota Bengkulu dan tidak semua mahasiswa berasal dari jurusan ilmu eksak bahkan ada yang berasal dari sekolah-sekolah kejuruan ilmu sosial yang tidak mendapatkan materi matriks. Hal ini menjadi pertimbangan dalam menyusun dan membuat materi modul dan lembar kegiatan mahasiswa.

Mahasiswa-mahasiswa ini pada umumnya berada pada kisaran umur 19 tahun ke atas yang menurut Piaget bahwa kemampuan berfikir orang pada usia ini memasuki tahapan opersional formal. Karakteristik tahap ini adalah diperolehnya kemampuan untuk berfikir secara abstrak, menalar secara logis dan menarik kesimpulan dari informasi yang tersedia. Namun pada kenyataannya, beberapa orang tidak sepenuhnya mencapai perkembangan sampai tahap ini, sehingga ia tidak mempunyai keterampilan berfikir sebagai seorang dewasa dan tetap menggunkan penalaran dari tahap operasional konkret. Analisis terhadap sikap mahasiswa menunjukkan bahwa secara umum tertarik dengan Ajabar Linear, hanya saja belum memahami secara maksimal.

\section{Memilih dan mengembangkan Materi Pembelajaran}

Pada bagian ini dilakukan pemilihan dan identifikasi materi yang disusun secara sistematis untuk konsep-konsep yang relevan untuk dipelajari. Peta konsep ini diguakan untuk menata dan menghubungkan apa yang akan ditulis. Menurut Prastowo (2014) bahwa membuat peta pikiran dalam menyusun bahan ajar dimulai dengan menelusuri dan mengidentifikasi berbagai materi pokok dan materi-materi penjelas yang akan ditulis.

\section{Mengembangkan Produk Awal}

Setelah dilakukan analisis materi terhadap kebutuhan bahan ajar dan dengan mempertimbangkan keterbatasan-keterbatasan yang ada, penelitian ini hanya mengembangkan bahan ajar berupa modul dan lembar kegiatan mahasiswa pada dua materi saja yaitu pertama, Sistem Persamaan Linear dan Matriks dan kedua, Determinan. 
Kemudian mulai dilakukan pengumpulan bahan-bahan referensi yang mendukung pelaksanaan penelitian dari berbagai sumber berupa buku-buku teks, artikel-artikel hasil penelitian yang juga diperoleh melalui browsing secara online.

Rancangan awal dalam penelitian ini merupakan rancangan semua kegitan yang dilakukan sebelum ujicoba terbatas dilaksanakan. Pada tahapan ini dihasilkan rancangan awal bahan ajar berupa modul dan lembar kegiatan mahasiswa.

\section{Rancangan Awal Modul}

Modul yang dirancang disesuaikan dengan pendekatan pembelajaran dan indikator kemampuan berfikir kreatif matematis. Selain itu juga mempertimbangkan karakteristikkarakteristik seperti tujuan pembelajaran yang jelas, materi disusun dalam unit-unit kegiatan spesifik, bahasa yang sederhana dan komunikatif.

Karakteristik lain yang juga menjadi pertimbangan adalah modul yang dibuat dapat memberikan kesempatan mahasiswa mempelajari materi pembelajaran secara tuntas serta memuat instruksi dan paparan informasi yang bersifat membantu.

2. Rancangan Awal Lembar Kegiatan Mahasiswa (LKM)

Sama halnya dengan modul, Lembar Kegiatan Mahasiswa (LKM) yang dirancang disesuaikan dengan tahapan setiap kegiatan belajar. LKM yang dikembangkan mengarahkan mahasiswa untuk dapat mengembangkan kemampuan befikir kreatif matematis, di antaranya mahasiswa dapat melakukan proses penemuan sendiri supaya dapat memberikan jawaban yang bervariasi, dapat memberikan jawaban secara terperinci dalam mengungkapkan gagasan-gagasan baru.

Permasalahan yang disajikan dibuat kontekstual agar mahasiswa lebih mudah dalam memahami konsep materi dan mengidentifikasi permasalahan yang dipelajari. Rancangan LKM dibuat semenarik mungkin dengan adanya warna dan gambar pendukung agar dapat menumbuhkan motivasi mahasiswa dalam belajar.

\section{Evaluasi Teman Sejawat dan Revisi}

Setelah modul dan LKM selesai dirancang kemudian dilakukan evaluasi teman sejawat yang terdiri atas 4 orang untuk isi atau konten dan menilai konstruksi yang ada pada kedua bahan ajar tersebut. Secara khusus kriteria yang digunakan adalah kelayakan isi, kebahasaan, sajian dan kegrafisan.

Data-data tersebut dianalisis secara deskriptif untuk menentukan kelayakan isi dan kelayakan desain pesan (media). Hasil evaluasi diperoleh sebagai berikut. 
Tabel 1. Hasil Evaluasi Teman Sejawat Terhadap Modul Mata Kuliah Aljabar Linear

\begin{tabular}{clcc}
\hline No. & \multicolumn{1}{c}{ Kriteria } & Skor(\%) & Kategori \\
\hline A. & Kelayakan Isi & \multicolumn{2}{c}{} \\
1 & Kesesuaian dengan SK dan KD & 93,75 & Sangat Baik \\
2 & Kesesuaian dengan perkembangan mahasiswa & 87,5 & Baik \\
3 & Kesesuaian dengan kebutuhan bahan ajar & 81,25 & Baik \\
4 & Kebenaran substansi materi & 93,75 & Sangat Baik \\
5 & Manfaat untuk penambahan wawasan pengetahuan & 87,5 & Baik \\
6 & Kesesuaian dengan nilai-nilai, moralitas, sosial & 87,5 & Baik \\
B. & Kebahasaan & & \\
1 & Keterbacaan & 93,75 & Sangat Baik \\
2 & Kejelasan informasi & 87,5 & Baik \\
3 & Kesesuaian dengan kaidah Bahasa Indonesia yang baik dan benar & 93,75 & Sangat Baik \\
4 & Penggunaan bahasa secara efektif dan efisien (jelas dan singkat) & 93,75 & Sangat Baik \\
C & SAJIAN & & \\
1 & Kejelasan tujuan (indikator) yang ingin dicapai & 87,5 & Baik \\
2 & Urutan penyajian & 93,75 & Sangat Baik \\
3 & Pemberian motivasi, daya tarik & 87,5 & Baik \\
4 & Interaktivitas (pemberian stimulus dan respon) & 81,25 & Baik \\
5 & Kelengkapan informasi & 81,25 & Baik \\
D & KEGRAFISAN & & \\
1 & Penggunaan font (jenis dan ukuran) & 87,5 & Baik \\
2 & Lay out, tata letak & 81,25 & Baik \\
3 & Ilustrasi, grafis, gambar foto & 87,5 & Baik \\
4 & Desain tampilan & 93,75 & Sangat Baik \\
\hline
\end{tabular}

Berdasarkan hasil evaluasi Tabel 1, semua evaluator berpendapat bahwa bahan ajar tersebut sudah baik dari segi isi, bahasa, sajian maupun media. Ada beberapa komentar yang diberikan antara lain, pada cover dapat ditambahkan gambar ilustrasi yang berhubungan dengan konteks matematika terutama Aljabar Linear.

Lembar Kegiatan Mahasiswa (LKM) juga dievaluasi dengan kriteria seperti pada modul, baik dari bahasa dan konten. Tabel 2 berikut menyajikan hasil evaluasi LKM.

Tabel 2. Hasil Evaluasi Teman Sejawat Terhadap LKM Mata Kuliah Aljabar Linear

\begin{tabular}{|c|c|c|c|}
\hline No. & Kriteria & $\operatorname{Skor}(\%)$ & Kategori \\
\hline A. & Kelayakan Isi & & \\
\hline 1 & Kesesuaian dengan SK dan KD & 87,5 & Baik \\
\hline 3 & Kesesuaian dengan kebutuhan bahan ajar & 87,5 & Baik \\
\hline 4 & Kebenaran substansi materi & 93,75 & Sangat Baik \\
\hline 5 & Manfaat untuk penambahan wawasan pengetahuan & 81,25 & Baik \\
\hline B. & Kebahasaan & & \\
\hline 1 & Keterbacaan & 93,75 & Sangat Baik \\
\hline 2 & Kejelasan informasi & 93,75 & Sangat Baik \\
\hline 3 & Kesesuaian dengan kaidah Bahasa Indonesia yang baik dan benar & 93,75 & Sangat Baik \\
\hline 4 & Penggunaan bahasa secara efektif dan efisien (jelas dan singkat) & 87,5 & Baik \\
\hline 3 & Pemberian motivasi, daya tarik & 81,25 & Baik \\
\hline 4 & Interaktivitas (pemberian stimulus dan respon) & 87,5 & Baik \\
\hline 5 & Kelengkapan informasi & 81,25 & Baik \\
\hline $\mathrm{D}$ & KEGRAFISAN & & \\
\hline 1 & Penggunaan font (jenis dan ukuran) & 93,75 & Sangat Baik \\
\hline 2 & Lay out, tata letak & 81,25 & Baik \\
\hline 3 & Ilustrasi, grafis, gambar foto & 87,5 & Baik \\
\hline
\end{tabular}




\begin{tabular}{llll}
\hline 4 & Desain tampilan & 87,5 & Baik \\
\hline
\end{tabular}

Secara garis besar, keempat evaluator memberikan penialain yang baik terhadap LKM yang dikembangkan. Meskipun demikian, perbaikan terus dilakukan untuk penyempurnaan dan hasil yang lebih baik. Misalnya pengecekan ketikan, perbaikan tata letak dan warna gambar yang ditampilkan.

Dari hasil ini dapat dibuat kesimpulan bahwa setelah melakukan beberapa perbaikan, bahan ajar modul dan LKM yang dikembangkan sudah valid dan dapat digunakan untuk tahapan selanjutnya. Setelah dilakukan beberapa perbaikan, diperoleh draf I yang kemudian digunakan untuk uji coba terbatas pada skala kecil pada 10 orang responden mahasiswa yang sudah pernah mendapatkan materi yang dikembangkan pada bahan ajar tersebut.

\section{Uji Coba Skala Kecil}

Hasil revisi pada beberapa bagian setelah dievaluasi oleh para evaluator menghasilkan draf II yang kemudian diujicobakan pada 10 orang responden yang dipilih secara acak. Responden ini adalah mahasiswa Pendidikan Matematika FKIP Universitas Muhammadiyah Bengkulu yang sudah pernah mendapatkan kuliah Ajjabar Linear. Uji coba ini untuk melihat faktor kejelasan dan keterbacaan bahan ajar yang dikembangkan, sehingga dapat dilakukan penyempurnaan dan menghasilkan draf III.

Respon mahasiswa terhadap modul yang diberikan pada uji coba ini memberikan hasil seperti pada tabel berikut ini.

Tabel 3. Respon MahasiswaTerhadap Modul Mata Kuliah Aljabar Linear

\begin{tabular}{clcc}
\hline No & \multicolumn{1}{c}{ Kriteria } & Skor (\%) & Kategori \\
\hline 1. & Bahasa yang digunakan pada modul mudah dipahami & 90 & Sangat Baik \\
2. & Istilah atau notasi yang digunakan pada modul dapat dipahami & 85 & Baik \\
3. & Urutan materi dan penyajiannya logis atau sistematis & 87,5 & Baik \\
4. & Modul mudah dan praktis digunakan & 92,5 & Sangat Baik \\
5. & Modul disusun cukup menarik dan mendorong belajar & 87,5 & Baik \\
6. & $\begin{array}{l}\text { Gambar-gambar yang ditampilkan cukup menarik dan mendukung } \\
\text { objek yang dijelaskan. }\end{array}$ & 85 & Baik \\
7. Informasi-informasi pendukung dalam modul cukup membantu & 80 & Sangat Baik \\
8. & $\begin{array}{l}\text { Contoh soal dan soal-soal latihan cukup membantu pemantapan } \\
\text { pemahaman materi. }\end{array}$ & 92,5 & \\
\hline
\end{tabular}

Secara umum, semua mahasiswa memberikan respon yang sangat baik terhadap modul hasil pengembangan yang digunakan sebagai bahan ajar pada penelitian ini. 
Sejumlah masukan yang sifatnya substantif diberikan mahasiswa pada saat uji coba kelompok kecil ini.

Beberapa komentar yang diberikan mahasiswa antara lain:

1. Modul tersebut cukup menarik, mudah dipahami dan memudahkan dalam memahami materi.

2. Modul dapat membuat minat belajar lebih baik, sehingga perlu dikembangkan secara terus-menerus.

3. Agar lebih banyak memberikan materi yang bersifat kontekstual.

Sama halnya dengan modul, respon mahasiswa terhadap lembar kegiatan mahasiswa (LKM) juga sangat baik. Hal ini seperti terlihat pada tabel 5 berikut.

Tabel 4. Respon MahasiswaTerhadap Lembar Kegiatan Mahasiswa (LKM) Mata Kuliah Aljabar Linear

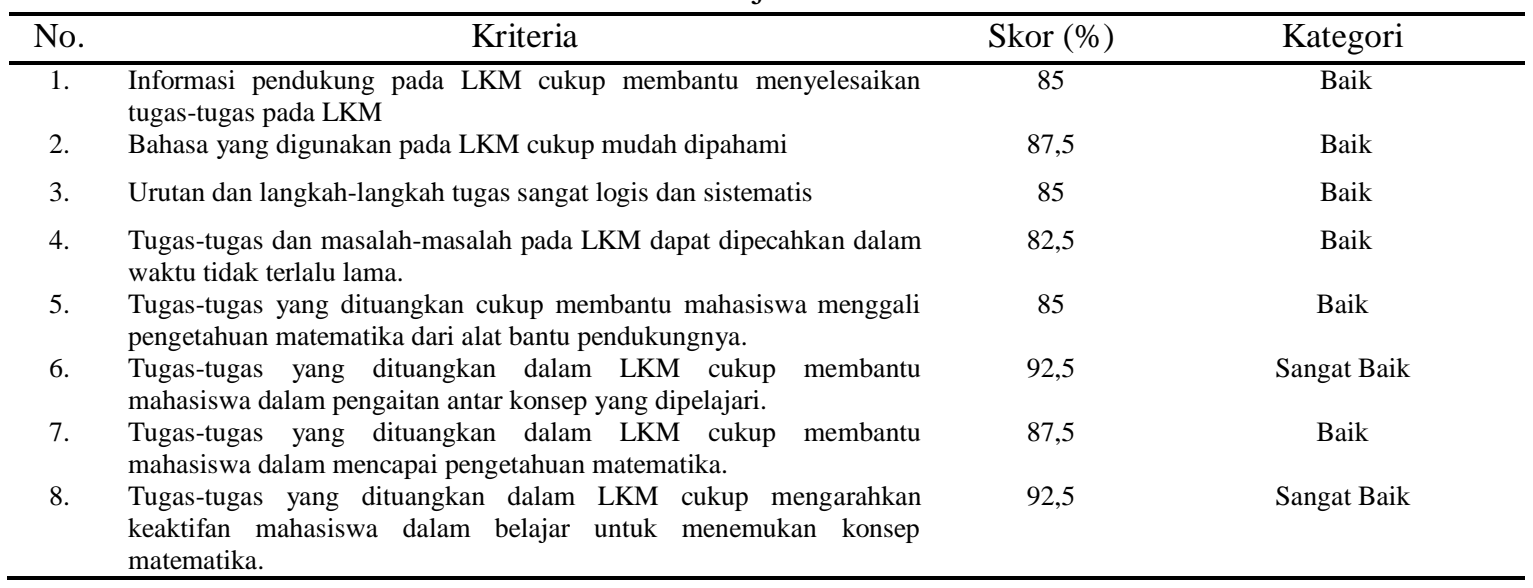

Berdasarkan hasil respon mahasiswa terhadap modul dan LKM yang dikembangkan menunjukkan hasil yang sangat baik, maka tidak dilakukan lagi revisi terhadap draf III ini. Artinya bahan ajar tersebut dapat dilanjutkan dan layak untuk digunakan pada uji lapangan pada proses pembelajaran.

\section{Hasil Uji Coba Lapangan}

Tahapan terakhir penelitian ini adalah uji lapangan dengan melakukan proses pembelajaran berbantuan modul dan Lembar Kerja Mahasiswa (LKM) yang sudah diperoleh dari tahapan sebelumnya. Pembelajaran ini dengan menerapkan model pembelajaran Treffinger dengan tujuan dapat mengembangkan kemampuan berpikir kreatif matematis mahasiswa terutama dalam kemampuan untuk mengeksplorasi pengetahuan yang dimiliki oleh mahasiswa. 


\section{KESIMPULAN}

Berdasarkan hasil penelitian ini, dapat dismpulkan bahwa bahan ajar modul dan Lembar Kegiatan Mahasiswa (LKM) yang dikembangkan sudah valid dan layak diujicobakan pada proses pembelajaran untuk dapat memfasilitasi kemampuan berfikir kreatif matematis. Bahan ajar tersebut menarik dan dapat menimbulkan motivasi belajar di tengah keterbatasan bahan ajar dan mengurangi rasa malas belajar di rumah.

Penelitian yang telah dilakukan diperoleh luaran berupa bahan ajar modul dan lembar kegiatan mahasiswa (LKM) yang dapat dugunakan pada pembelajaran Aljabar Linear terutama pada materi Sistem Persamaan Linear dan Matriks, dan Determinan. Secara garis besar bahan ajar yang digunakan sudah dapat membantu mahasiswa sebagai sumber belajar terutama belajar mandiri. Akan tetapi dalam pengembangan kemampuan berfikir kreatif matematis masih perlu terus dikembangkan mengingat latar belakang mahasiswa yang masih memiliki kemampuan di bawah rata-rata.

\section{REFERENSI}

Ahmad, S.S. (2009). Pengantar Pegembangan Bahan Ajar di Perguruan Tinggi. Disampaikan pada Pelatihan Pengembangan Bahan Ajar Bagi Dosen. Pekanbaru 30 April 2009.

Grieshober, W.E. (2004). Continuing a Dictionary of Creativity Terms \& Definition. New York: International Center for Studies in Creativity State University of New York College at Buffalo. Diperoleh dari http://www.buffalostate.edu/orgs/cbir/ReadingRoom/theses/Grieswep.pdf.

Livne, N.L. (2008). Enhanching Mathematical Creativity through Multiple Solution to Open-Ended Problems Online. Diperoleh dari http://www.iste.org/Content/NavigationMenu/Research/NECC_Research_P aper_Archives/NECC2008/Livne.pdf.

Mahmudi, A. (2010). Mengukur Kemampuan Berpikir Kreatif Matematis. Makalah disajikan pada Konferensi Nasional Matematika XV UNIMA Manado, 30 Juni - 3 Juli 2010. Universitas Negeri Yogyakarta.

Mann, E. L. (2005). Mathematical Creativity and School Mathematics: Indicators of Mathematical Creativity in Middle School Students. Disertasi University of Connecticut. Diperoleh dari http://www.gifted.uconn.edu/Siegle/Dissertations/Eric\%20Mann.pdf.

McGregor, D. (2007). Developing Thinking Developing Learning. Poland: Open University Press.

Martin. (2009). Convergent and Divergent Thinking. Diperoleh dari http://www.eruptingmind.com/convergent-divergent-creative-thinking/

Park, H. (2004). The Effects of Divergent Production Activities with Math Inquiry and Think Aloud of Students With Math Difficulty. (Disertasi). Diperoleh dari http://txspace.tamu.edu/bitstream/handle/1969.1/

Prastowo, A. (2014). Pengembangan Bahan Ajar Tematik (Tinjauan Teoretis dan Praktik). Jakarta: Kencana Prenadamedia Grup. 
Rudi, C. (2010). Pengembangan modul pemrograman pascal untuk mahasiswa program studi pendidikan matematika STKIP PGRI SUMBAR. (Tesis tidak diterbitkan). Padang: Program Pasca Sarjana UNP.

Siswono, T.Y.E. (2009), Meningkatkan Kemampuan Berpikir Kreatif Siswa Melalui Pemecahan Masalah Tipe "What's Another Way". Diperoleh dari http://tatagyes.files.wordpress.com

Soenarto. (2005). Metodologi Penelitian untuk Peningkatan Kualitas Pembelajaran Penelitian Pengembangan. Makalah disampaikan pada Pelatihan Nasional Penelitian Peningkatan Kualitas Pembelajaran dan Penelitian Tindakan Kelas (PPKP \& PTK), Bagi dosen LPTK, di Denpasar, 1-4 Agustus 2005 dan di Batam, 8-11 Agustus 2005. Halaman 6 dan 8. Depdiknas Dikti Direktorat Pembinaan Tenaga Kependidikan dan Ketenagaan Pendidikan Tinggi (PPTK dan KPT).

Suprawoto. (2009). Mengembangkan Bahan Ajar dengan Menyusun Modul. Diperoleh dari http://www.scribd.com

Trisnaningsih. (2007). Pengembangan Bahan Ajar untuk Meningkatkn Pemahaman Materi Mata Kuliah Demografi Teknik. Jurnal Ekonomi \& Pendidikan volume 4 Nomor 2 November 2007. FKIP Universitas Lampung.

Worthington, M. (2006). Creativity Meets Mathematics. Diperoleh dari http://www.childrens-mathematics.net/creativity_meets_mathematics.pdf. 